\title{
Pengaruh Daya Saing Destinasi Wisata Terhadap Implementasi Re-Visiting Commitmen Wisatawan Objek Wisata Di Kota Palembang
}

\author{
Mutiara Lusiana Annisa ${ }^{*}$, Ganda Hutasoit ${ }^{2}$ \\ Politeknik PalComTech \\ Korespondensi*: mutiara_annisa@palcomtech.ac.id
}

\begin{abstract}
Abstrak
Penelitian ini bertujuan untuk mengetahui pengaruh daya saing destinasi wisata terhadap implementasi re-visiting commitmen wisatawan/turis ke objek-objek wisata dikota Palembang. Penelitian ini menggunakan pendekatan kuantitatif dengan alat analisa regresi. Populasi dalam penelitian ini adalah wisatawan lokal/domestik dan mancanegara yang berkunjung ke objek wisata di Palembang. Sampel yang dilibatkan dalam penelitian ini adalah 240 responden yang dipilih secara acak dan terbagi dalam 120 responden wisatawan lokal dan 120 wisatawan mancanegara. Hasil analisis untuk wisatawan lokal menunjukkan bahwa variabel: 1) Kebijakan, perencanaan, dan pengembang destinasi dan 2) Manajemen destinasi, berpengaruh terhadap implementasi re-visiting commitmen wisatawan domestik. Sedangkan variabel: 1) Sumber dan daya tarik utama dan 2) Persyaratan dan penjelasan faktor penentu tidak berpengaruh terhadap re-visiting commitment wisatawan domestic pada objek-objek wisata di kota Palembang. Untuk hasil analisis wisatawan mancanegara menunjukkan bahwa variabel: 1) Sumber dan daya tarik dan 2) manajemen destinasi, berpengaruh terhadap re-visiting commitment, sedangkan variabel: 1) Faktor dan sumber pendukung, 2) kebijakan, perencanaan dan pengembangan destinasi, 3) persyaratan dan penjelasan faktor penentu, tidak berpengaruh terhadap revisiting commitment.
\end{abstract}

Kata Kunci : Daya Saing Destinasi Wisata, Re-Visiting Commitment

\begin{abstract}
This study aims to determine the influence of the competitiveness of tourist destinations on the implementation of re-visiting commitment of tourists / tourists to tourism objects in the city of Palembang. This study uses a quantitative approach with regression analysis tools. The population in this study are local / domestic and foreign tourists who visit tourist attractions in Palembang. The samples included in this study were 240 respondents who were randomly selected and divided into 120 local tourist respondents and 120 foreign tourists. The analysis results for local tourists show that the variables are: 1) Policy, planning, and destination developers and 2) Management of destinations, influencing the implementation of re-visiting commitments of domestic tourists. While the variables: 1) Source and main attraction and 2) Requirements and explanation of determinants do not affect the re-visiting commitment of domestic tourists on tourism objects in the city of Palembang. For the analysis of foreign tourists shows that the variables are: 1) source and attractiveness and 2) destination management, influencing re-visiting commitment, while variables: 1) supporting factors and sources, 2) policy, destination planning and development, 3) requirements and explanation of determinants, has no effect on re-visiting commitment.
\end{abstract}

Keywords: Travel Destination Competitiveness, Re-Visiting Commitment

\section{A. PENDAHULUAN}

Pembangunan pariwisata sebagai suatu industri menjadi sesuatu hal yang penting dalam rangka meningkatkan pertumbuhan ekonomi yaitu dengan mengeksploitasi keindahan alam, seni budaya, dan keramahtamahan. Untuk meningkatkan pertumbuhan ekonomi, maka banyak para pakar merasa khawatir dan menganggap penting adanya perencanaan yang matang dalam pengembangan pariwisata. Pemikiran itu tentunya berdasarkan pertimbangan bahwa pariwisata sebagai suatu industri diharapkan dapat 
memacu pertumbuhan ekonomi di daerah tujuan wisata atau negara yang dikunjungi wisatawan.

Objek "daya tarik" yang menjadi bagian dari daya saing wisata budaya itu dapat berkisar pada beberapa hal seperti kesenian (Seni rupa dan segala bentuk seni pertunjukan), tata busana, boga, upacara adat, serta keterampilan-keterampilan khusus fungsional seperti membuat alat-alat dan lain- lain. Objek-objek itu tidak jarang dikemas khusus bagi penyajian untuk turis dengan maksud agar menjadi lebih menarik.

Kota Palembang yang terkenal dengan sebutan kota Bumi Sriwijaya merupakan salah satu wilayah tujuan wisata yang menawarkan berbagai macam objek wisata baik objek wisata alam, wisata budaya dan religi, maupun wisata kuliner dengan semua potensi, keunikan, dan kelebihan yang dimilikinya. Kota Palembang juga baru saja terpilih menjadi model wisata olahraga nasional oleh kementrian pariwisata dikarenakan seringnya kota Palembang menggelar event olahraga berskala nasional maupun internasional yang dilaksanakan di kawasan jakabaring sport city seperti SEA Games 2011, Islamic Solidarity Games, hingga Asian Games yang telah dilaksanakan pada tahun 2018 ini.

Banyaknya event nasional dan internasional yang diadakan di kota Palembang, maka akan meningkatkan promosi wisata di kota Palembang. Adanya pembangunan infrastruktur pendukung di kota Palembang maka akan meningkatkan promosi. Meskipun pemerintah daerah sudah banyak melakukan usaha promosi untuk menarik wisatawan akan tetapi diperlukan cara promosi yang lebih baik untuk menarik minat wisatawan berkunjung ke objek-objek wisata di kota Palembang.

Sebagai upaya untuk dapat meningkatkan jumlah wisatawan baik domestik dan mancanegara, lama tinggal dan jumlah pengeluaran wisatawan baik domestic maupun mancanegara selama berwisata di kota Palembang maka perlu dipahami kualitas tempat tujuan wisata dan pengaruhnya terhadap perilaku paska pembelian yaitu kepuasan dan niat berkunjung kembali sebagai bentuk komitmen atas kepuasan wisatawan baik domestik maupun mancanegara selama berwisata di kota Palembang.

Berdasarkan latar belakang di atas maka topik yang akan dibahas dalam penelitian ini adalah pengaruh daya saing destinasi wisata terhadap re-visiting commitment wisatawan ke objek-objek wisata di kota Palembang.

\section{B. TINJAUAN PUSTAKA}

\section{Daya Saing Destinasi Wisata}

Daya saing merupakan kemampuan usaha yang dimiliki suatu perusahaan dalam industri dalam mengatasi berbagai lingkungan yang dihadapi. Daya saing ditentukan oleh keunggulan bersaing suatu perusahaan dan sangat tergantung pada tingkat sumber daya rrelatif yang dimilikinya atau disebut keunggulan kompetitif. Menurut witt (1994) daya tarik tempat tujuan wisata merupakan motivasi utama bagi wisatawan untuk melakukan kunjungan wisata. Menurut destinasi wisata dikelompokkan menjadi empat 
daya tarik yaitu :

1. Daya tarik wisata alam yang meliputi pemandangan alam daratan, pemandangan alam lautan, pantai, iklim atau cuaca.

2. Daya tarik wisata berupa arsitektur bangunan yang meliputi bangunan dan arsitektur bersejarah, bangunan dan arsitektur bersejarah, bangunan dan arsitektur modern, arkeologi.

3. Daya tarik wisata yang dikelola khusus yang meliputi tempat peninggalan kawasan industri seperti yang ada di Inggris, Theme Park di Amerika, Darling Harbour di Australia.

4. Daya tarik wisata budaya yang meliputi teater, museum, tempat bersejarah, adat istiadat, tempat-tempat religius, peristiwa-peristiwa khusus seperti festival dan drama bersejarah, dan heritage seperti warisan peninggalan budaya.

5. Daya tarik wisata sosial seperti gaya hidup penduduk di tempat tujuan wisata.

\section{Re-Visiting Commitmen Wisatawan}

Niat beli kembali didefiniskan sebagai purchase intention yaitu keinginan yang kuat untuk membeli kembali (Fullerton dan Taylor dalam Jasfar, 2002). Menurut Miller, Glawter and Primbram dalam Iman Khalid Abdul Qader (2008) mendefiniskan purchases intention adalah keadaan mental seseorang yang mencerminkan rencana untuk melakukan beberapa tindakan dalam jangka waktu tertentu. Definisi ini diasumsikan sebagai anteseden langsung dari perilaku. Penerapannya dalam riset terhadap definis purchases intention adalah pelanggan akan melakukan tindakan pembelian kembali di waktu yang akan datang sebagai respon langsung dari perilaku paska pembelian dalam jangka waktu tertentu. Sedangkan menurut Assael (1998), purchase intention merupakan keinginan pelanggan untuk melakukan pembelian berulang di waktu yang akan datang. Penelitian yang dilakukan Cronin dan Taylor (1992), Woodside, Frey dan Daily menyatakan bahwa purchases intention secara positif mendukung hubungan antara kepuasan pelanggan dengan perilaku niat membeli kembali.

Purchases intention dalam hubungannya dengan kunjungan wisatawan dalam pembelian jasa pariwisata disebut sebagai behaviora intention to visit. Pengembangan konseptualisasi model hubungan antara kualitas pelayanan yang dirasakan, nilai layanan, dan kepuasan serta pengaruh relatifnya terhadap perilaku niat beli seperti dikemukakan oleh Baker and Crompton (2000) dan Tian Cole et al (2002) yang menyatakan bahwa persepsi kualitas layanan dan kepuasan telah terbukti menjadi prediktor yang baik dari niat kunjungan kembali wisatawan. Menurut Cronin et al (2000) mengemukakan bahwa persepsi kualitas layanan yang dirasakan merupakan tanggapan kognitif terhadap jasa yang ditawarkan, sedangkan kepuasan secara keseluruhan merupakan respon emosional yang didasarkan pada fenomena pandangan secara menyeluruh. Hal ini juga dikuatkan oleh Bolton and Drew (1991) yang 
memberikan dukungan empiris terhadap antara kualitas dan nilai yang dirasakan. Temuan mereka menunjukkan bahwa kualitas pelayanan yang dirasakan menjelaskan sebagian besar varians terhadap service value, dan nilai yang dirasakan adalah ukuran yang baik terhadap evaluasi menyeluruh oleh wisatawan terhadap kualitas layanan dari pada kualitas pelayanan yang dirasakan. Hubungan antara persepsi wisatawan terhadap harga, kualitas dan nilai diuji oleh Zeithaml (1988) yang melaporkan bahwa kualitas pelayanan akan meningkatkan persepsi terhadap nilai pelayanan yang dirasakan dan juga akan memunculkan niat untuk membeli kembali.

Manfaat spesifik kepuasan pelanggan disebutkan mempunyai keterkaitan positif dengan niat pembelian kembali, dan berpotensi menjadi sumber pendapatan masa depan, terutama sumber pendapatan masa depan, terutama melalui pembelia ulang, baik cross selling, dan up-selling (Tjiptono,2005). Kepuasan pelanggan dapat memberikan beberapa manfaat, diantaranya hubungan antara perusahaan dan pelanggannya menjadi harmonis, memberikan dasar yang baik bagi pembelian ulang dan terciptanya loyalitas pelanggan, serta membentuk suatu rekomenasi dari mulut ke mulut yang menguntungkan bagi perusahaan. kepuasan pelanggan juga memperkuat perilaku terhadap merek dan kemungkinan besak akan mengarahkan pada pembelian terhadap merek yang sama (Assael,1995).

Dari pokok pikiran yang telah dibangun diatas, maka hipotesis yang berlaku pada penelitian ini adalah:

Ho : Daya Saing Destinasi Wisata tidak berpengaruh terhadap re-visiting commitment wisatawan baik domestik maupun mancanegara pada objek wisata di kota Palembang

H1 : Daya Saing Destinasi Wisata berpengaruh terhadap implementasi re-visiting commitment wisatawan baik domestik maupun mancanegara pada objek wisata di kota Palembang.

\section{METODE PENELITIAN}

Penelitian ini menggunakan pendekatan kuantitatif dengan menggunakan teknik analisa regresi. Populasi dalam penelitian ini adalah para wisatawan domestik ataupun mancanegara yang berkunjung ke objek wisata di kota Palembang. Sedangkan sampel yang dilibatkan sebagai responden adalah para wisatawan yang berkunjung ke Benteng Kuto Besak, Kampung Al Munawar, Gelora Sriwijaya, dan Pulau Kemaro sebanyak 240 responden yang diambil dengan metode acak (random sampling), yang terbagi atas 120 responden domestik dan 120 responden wisatawan mancanegara. Data yang digunakan adalah data primer yang diperoleh melalui kuisioner yang disebar langsung kepada responden, berisi sejumlah pertanyaan dengan opsi jawaban mulai dari Sangat Setuju hingga Sangat Tidak Setuju dan dinilai menggunakan skala Likert. 


\section{HASIL PENELITIAN DAN PEMBAHASAN}

Untuk mengukur kualitas data yang akan diolah, peneliti melakukan uji validitas data. Menurut wiratna (2015), uji validitas sebaiknya dilakukan pada setiap butir pertanyaa di uji validitasnya. Hasil $r$ hitung kita bandingkan dengan $r$ tabel dimana $\mathrm{df}=$ $\mathrm{n}-2$ dengan signifikansi 5\%. Jika $r$ tabel lebih kecil daripada $r$ hitung maka dinyatakan valid.

\section{Uji Validitas dan Uji Reliabilitas Data Pada Responden Wisatawan Mancanegara}

Berdasarkan hasil pengujian validitas, dengan menggunakan jumlah responden sebanyak 120 responden yang berasal dari responden mancanegara yang berada pada objek wisata dikawasan kota Palembang yang terdiri dari empat lokasi yang masih berada dikawasan kota Palembang yaitu kawasan pertama yaitu benteng kuto besak (BKB) jembatan ampera dan sungai musi, kawasan kedua yaitu gelora sriwijaya, kawasan ketiga yaitu pulau kemaro, dan kawasan terakhir yaitu kampung Al Munawar maka nilai $\mathrm{r}$ tabel dapat diperoleh melalui tabel $\mathrm{r}$ product moment pearson dengan $\mathrm{df}$ $($ degree of freedom $)=\mathrm{n}-2$, jadi $\mathrm{df}=120-2=118$, maka $\mathrm{r}$ tabel didapat sebesar 0,179 (dengan tingkat signifikansi 0,05).

Hasil uji validitas tersebut menunjukkan bahwa nilai Corrected Item-Total Correlation $\mathrm{r}$ (hitung) $>$ dari 0,179 ( $\mathrm{r}$ tabel) pada seluruh butir pernyataan (46 Item) pada semua variabel adalah valid, sehingga data dapat dianalisis lebih lanjut. Menurut Wiratna (2015) Uji reliabilitas dapat dilakukan secara bersama-sama terhadap seluruh butir pertanyaan atau pernyataan, jika nilai Alpha lebih besar 0,60 maka reliable. Berdasarkan hasil pengujian untuk responden lokal, maka didapatkan nilai Cronbach's sebesar 0,893 atau $89,3 \%$. Hasil uji validitas di atas menunjukkan bahwa nilai Cronbach's Alpha $>$ dari 0,60 ( $\mathrm{r}$ tabel) pada seluruh butir pernyataan (item) pada semua variabel adalah reliable.

\section{Uji Validitas dan Uji Reliabilitas Data Pada Responden Domestik}

Berdasarkan hasil pengujian validitas, dengan menggunakan jumlah responden sebanyak 120 responden yang berasal dari responden domestik yang berada pada objek wisata dikawasan kota Palembang yang terdiri dari empat lokasi yang masih berada dikawasan kota Palembang yaitu kawasan pertama yaitu benteng kuto besak (BKB) jembatan ampera dan sungai musi, kawasan kedua yaitu gelora sriwijaya, kawasan ketiga yaitu pulau kemaro, dan kawasan terakhir yaitu kampung Al Munawar maka nilai $\mathrm{r}$ tabel dapat diperoleh melalui tabel $\mathrm{r}$ product moment pearson dengan df (degree of freedom) $=\mathrm{n}-2$, jadi $\mathrm{df}=120-2=118$, maka $\mathrm{r}$ tabel didapat sebesar 0,179 (dengan tingkat signifikansi 0,05).

Berdasarkan hasil pengujian untuk responden lokal, maka didapatkan nilai Cronbach's sebesar 0,896 atau 89,6\%. Hasil uji validitas di atas menunjukkan bahwa nilai Cronbach's Alpha $>$ dari 0,60 ( $\mathrm{r}$ tabel) pada seluruh butir pernyataan (item) pada semua variabel adalah reliable.

\section{Uji Koefisien Determinasi $\left(\mathbf{R}^{2}\right)$ Responden Mancanegara}

Hasil pengujian $\left(\mathrm{R}^{2}\right)$ dan adjusted $\mathrm{r}$-squared dapat dilihat pada tabel sebagai berikut : 
Tabel 1: Hasil Uji Koefisien Determinasi $\left(\mathbf{R}^{2}\right)$ Responden Mancanegara

\begin{tabular}{llrrrr}
\hline \multicolumn{6}{c}{ Model Summary $^{\mathrm{b}}$} \\
\hline Model & $\mathrm{R}$ & R Square & $\begin{array}{c}\text { Adjusted R } \\
\text { Square }\end{array}$ & $\begin{array}{c}\text { Std.Error of } \\
\text { the Estimate }\end{array}$ & Durbin-Watson \\
\hline 1 &, $814^{\mathrm{a}}$ &, 662 &, 647 & 2,345 & 1,423 \\
\hline
\end{tabular}

Sumber: Data diolah (2018)

Berdasarkan uji koefisien determinasi terhadap responden mancanegara, maka nilai dari $\mathrm{R}$ adalah sebesar 0,814 atau sebesar $81,4 \%$. Sedangkan nilai dari $\mathrm{R}$ square menunjukkan sebesar 0,662 atau 66,2\%. Hal ini menunjukkan 66,2\% keadaan sebenarnya atau dalam arti sesungguhnya bahwa variabel daya saing destinasi wisata mampu mempengaruhi re-visiting commitment wisatawan mancanegara sebesar $66,2 \%$.

\section{Uji Koefisien Determinasi $\left(R^{2}\right)$ Responden Domestik}

Hasil uji koefisien determinasi $\left(\mathrm{R}^{2}\right)$ pada responden domestic adalah sebagai berikut :

Tabel 2: Hasil Uji Koefisien Determinasi $\left(\mathbf{R}^{2}\right)$ Responden Domestik

\begin{tabular}{lccccc}
\hline \multicolumn{6}{c}{ Model Summary $^{\mathbf{b}}$} \\
\hline Model & $\mathbf{R}$ & $\begin{array}{c}\mathbf{R} \\
\text { Square }\end{array}$ & $\begin{array}{c}\text { Adjusted } \\
\mathbf{R} \\
\text { Square }\end{array}$ & $\begin{array}{c}\text { Std.Error of } \\
\text { the Estimate }\end{array}$ & $\begin{array}{c}\text { Durbin- } \\
\text { Watson }\end{array}$ \\
\hline 1 & $\mathbf{7 4 6}^{\mathbf{a}}$ &, 557 &, 538 & 3,12079 & $\mathbf{1 , 0 7 3}$ \\
\hline
\end{tabular}

\section{Sumber : Hasil Penelitian (2018)}

Berdasarkan hasil uji koefisien determinasi terhadap responden domestik didapatkan hasil yaitu nilai $\mathrm{R}$ adalah sebesar 0,746 atau sebesar 74,6\% sedangkan nilai $\mathrm{R}$ Square menunjukkan nilai sebesar 0,557 atau sebesar $55,7 \%$ dalam arti yang sesungguhnya menunjukkan bahwa daya saing destinasi wisata memiliki pengaruh terhadap implemetnasi re-visiting commitment sebesar 55,7\% sedangkan sisanya 44,3\% dipengaruhi oleh model lainnya.

\section{Uji F}

Uji hipotesis secara simultan dilakukan untuk menguji pengaruh variabel bebas (X) secara bersama-sama terhadap variabel terikat (Y). Dalam uji hipotesis secara simultan, digunakan uji F. Hasil pengujian simultan disajikan dalam tabel di bawah ini:

Tabel 3: Hasil Uji F Responden Wisatawan Domestik ANOVA ${ }^{a}$

\begin{tabular}{llllll}
\hline Model & $\begin{array}{l}\text { Sum } \\
\text { Squares }\end{array}$ & of Df & $\begin{array}{l}\text { Mean } \\
\text { Square }\end{array}$ & F & Sig. \\
\hline Regression & 1229,167 & 5 & 245,833 & 44,710 &, $000^{\mathrm{b}}$ \\
\hline Residual & 626,825 & 114 & 5,498 & & \\
\hline Total & 1855,992 & 119 & & & \\
\hline
\end{tabular}

Sumber: Hasil Penelitian (2018)

Pada tabel di atas, merupakan tabel ANOVA. Tabel tersebut menjelaskan kelayakan model regresi untuk menjelaskan pengaruh variabel bebas terhadap variabel terikat. Untuk menguji apakah model linar tersebut sudah tepat atau belum, maka 
Fhitung pada tabel ANOVA perlu dibandingkan dengan Ftabel.

Ftabel tergantung dari probabilitas alpha dan degree of freedom. Degree of freedom (df) untuk menentukan Ftabel ada dua pembilang (N1) dan df (N2). Dimana $\mathrm{dfNI}=$ Jumlah variabel -1 , sehingga diperoleh $\mathrm{dfN} 1=6-1=5$, sedangkan dfN2 $=$ Jumlah sampel data - Jumlah variabel. Sehingga diperoleh dfN2 $=120-5=115$. Dengan demikian, jika menggunakan alpha $=5 \%$, maka diperoleh Ftabel $(\mathrm{NI}, \mathrm{N} 2)=$ 2.29. Berdasarkan uji F diperoleh nilai Fhitung $0.000<0.05$, hal ini menunjukkan bahwa pengaruh sumber dan daya tarik utama, faktor dan sumber pendukung, kebijakan, perencanaan, dan pengembangan destinasi, manajemen destinasi, dan persyaratan dan penjelasan faktor penentu secara simultan bepengaruh terhadap re-visiting commitment wisatawan/turis mancanegara pada objek-objek wisata di kota Palembang.

Hasil pengujian hipotesis dalam penelitian ini yang menyatakan bahwa daya saing destinasi wisata yang terdiri dari sumber dan daya tarik utama, faktor dan sumber pendukung, kebijakan, perencanaan, dan pengembangan destinasi, manajemen destinasi, dan persyaratan dan penjelasan faktor penentu secara parsial dan simultan terhadap revisting commitmen wisatawan mancangera. Hasil analisa menunjukkan bahwa hipotesis 1 di terima.

Adapun hasil uji $\mathrm{F}$ yang berguna untuk mengukur variabel independen terhadap variabel dependen secara parsial pada responden domestik adalah sebagai berikut :

Tabel 4: Hasil Uji F pada Responden Mancanegara

\begin{tabular}{lllllll}
\hline Model & $\begin{array}{l}\text { Sum of } \\
\text { Squares }\end{array}$ & df & $\begin{array}{l}\text { Mean } \\
\text { Square }\end{array}$ & F & Sig. \\
\hline 1 & Regression & 1396,380 & 5 & 279,276 & 28,675 &, $000^{\mathrm{b}}$ \\
\hline & Residual & 1110,287 & 114 & 9,739 & & \\
\hline & Total & 2506,667 & 119 & & & \\
\hline
\end{tabular}

Sumber : Hasil Penelitian (2018)

Berdasarkan hasil pengujian diatas, didapatkan hasil yaitu nilai Fhitung adalah sebesar $0,000<0,05$, hal ini menunjukkan bahwa pengaruh daya saing destinasi wisata yang diproksikan lewat variabel sumber dan daya tarik utama, faktor dan sumber pendukung, kebijakan, perencanaan, dan pengembangan destinasi, serta persyaratan dan penjelasan faktor penentu secara simultan berpengaruh terhadap re-visiting commitment wisatawan domestik pada objek-objek wisata di kota Palembang.

\section{Uji t}

Uji t digunakan untuk mengukur variabel independen terhadap variabel dependen secara parsial. Adapun hasil pengujian (uji t) pada responden mancanegara adalah sebagai berikut : 
Tabel 5: Hasil Uji -T pada Responden Mancanegara Coefficients ${ }^{\mathrm{a}}$

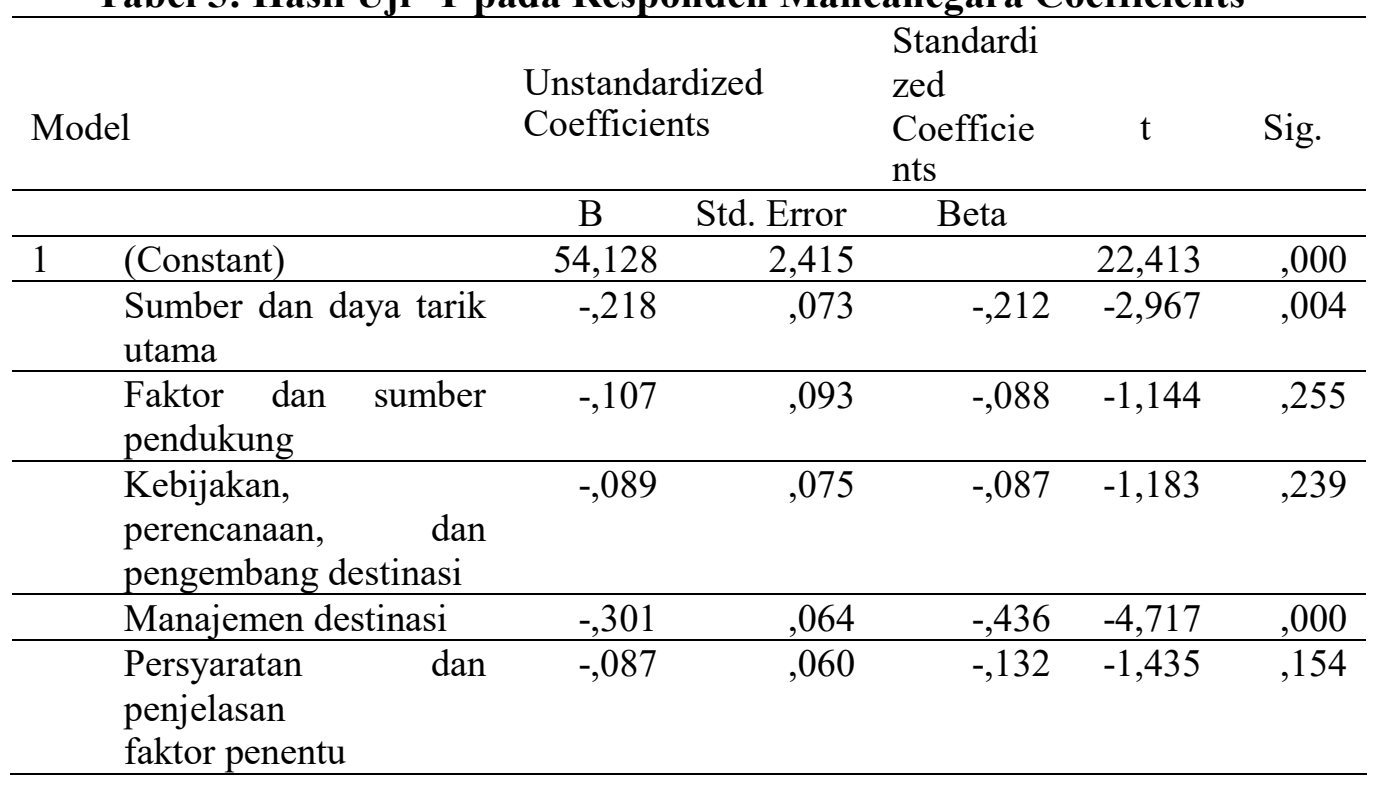

\section{Sumber : Hasil Penelitian (2018)}

Hasil uji $\mathrm{T}$ pada responden domestik, Sehingga di dapatkan hasil pengujian atau uji $\mathrm{T}$ untuk responden domestik sebagai berikut:

Tabel 6: Hasil Uji F pada Responden Domestik

\begin{tabular}{|c|c|c|c|c|c|c|}
\hline \multirow{2}{*}{\multicolumn{2}{|c|}{ Model }} & \multicolumn{2}{|c|}{$\begin{array}{l}\text { Unstandardized } \\
\text { Coefficients }\end{array}$} & \multirow{2}{*}{\begin{tabular}{l} 
Standardi \\
zed \\
Coefficie \\
nts \\
\multicolumn{1}{c}{ Beta } \\
\end{tabular}} & \multirow[t]{2}{*}{$\mathrm{t}$} & \multirow[t]{2}{*}{ Sig. } \\
\hline & & B & Std. Error & & & \\
\hline \multirow[t]{6}{*}{1} & (Constant) & 43,591 & 3,008 & & 14,493 &, 000 \\
\hline & $\begin{array}{l}\text { Sumber dan daya tarik } \\
\text { utama }\end{array}$ &,- 133 & ,097 &,- 111 & $-1,368$ &, 174 \\
\hline & $\begin{array}{l}\text { Faktor dan sumber } \\
\text { pendukung }\end{array}$ &,- 020 &, 071 &,- 021 &,- 282 &, 779 \\
\hline & $\begin{array}{l}\text { Kebijakan, } \\
\text { perencanaan, dan } \\
\text { pengembang destinasi }\end{array}$ & ,267 & ,099 &, 224 & 2,699 &, 008 \\
\hline & Manajemen destinasi &,- 260 &, 086 &,- 323 & $-3,024$ &, 003 \\
\hline & $\begin{array}{l}\text { Persyaratan dan } \\
\text { penjelasan } \\
\text { faktor penentu }\end{array}$ &,- 398 &, 079 &,- 521 & $-5,029$ &, 000 \\
\hline
\end{tabular}

\section{Sumber : Hasil Penelitian (2018)}

Berdasarkan hasil uji t pada responden lokal maka diketahui bahwa didapatkan hasil sebagai berikut, dimana hasil uji signifikansi (Sig) dinyatakan berpengaruh jika nilai signifikansi lebih kecil dari 0,05 . Berdasarkan uji $t$ didapatkan hasil yaitu Kebijakan, perencanaan, dan pengembang destinasi berpengaruh terhadap implementasi re-visting commitmen wisatawan domestik, manajemen destinasi berpengaruh terhadap implementasi re-visiting commitmen wisatawan domestik, sedangkan sumber dan daya tarik utama serta persyaratan dan penjelasan faktor penentu tidak berpengaruh terhadap re- visiting commitment wisatawan domestic pada objek-objek wisata di kota Palembang. 


\section{E. PENUTUP}

Dari hasil penelitian dan pembahasan yang dilakukan, maka diperoleh beberapa keseimpulan. Pertama, Hasil pengujian variabel daya saing destinasi wisata berpengaruh secara simultan terhadap re- visiting commitmen baik wisatawan domestik maupun wisatawan mancanegara pada objek-objek wisata di kota Palembang khusunya yang meliputi kawasan benteng kuto besak, gelora sriwijaya, kampung al munawar, dan pulau kemaro. Kedua, Secara parsial khususnya untuk responden yang berasal dari domestik, Kebijakan, perencanaan, dan pengembang destinasi berpengaruh terhadap implementasi re-visting commitmen wisatawan domestik, manajemen destinasi berpengaruh terhadap implementasi re-visiting commitmen wisatawan domestik, sedangkan sumber dan daya tarik utama serta persyaratan dan penjelasan faktor penentu tidak berpengaruh terhadap re-visiting commitment wisatawan domestic pada objekobjek wisata di kota Palembang. Dan terakhir, secara parsial khususnya untuk responden yang berasal dari mancanegara, didapatkan hasil penelitian yaitu sumber dan daya tarik berpengaruh terhadap re-visiting commitment, faktor dan sumber pendukung tidak berpengaruh terhadap re-visiting commitment, kebijakan, perencanaan dan pengembangan destinasi tidak berpengaruh terhadap re-visiting commitmen, manajemen destinasi berpengaruh terhadap re-visiting commitmen, serta persyaratan dan penjelasan faktor penentu tidak berpengaruh terhadap re-visiting commitmen.

\section{DAFTAR PUSTAKA}

Assael, Henry.1992. Consumer Behavior and Marketing Action. 4 th.ed. Pws-Kent Publishing Company,Inc

Assael, Henry, 1995. Costumer Behavior And Marketing Action, Keat Publishing Company, Boston.

Baker, D.A., \& Crompton, J.L. 2000. Quality, Satisfaction and behavioral intentions. Annals of Tourism Research, $27: 3,785-804$.

Cronin, J. Joseph, Jr., Michael K. Brady dan G. Thomas M. Hult.2000.Assessing the Effects of Quality, Value and Customer Satisfaction on Consumer Behavioral Intention in Service Environments, Journal of Retailing, 76(2)

Fandy Tjiptono, 2005. Pemasaran Jasa, Malang: Bayumedia Publishing

Fullerton, Gordon \& Shirley Taylor (2000)., The Role of Commitment in Service Relationship, Kingston, Ontario: School of Business Acadia University, limited publication. p.3-18.

Ghozali, Imam. 2011. "Aplikasi Analisis Multivariate Dengan Program SPSS". Semarang: Badan Penerbit Universitas Diponegoro.

Sujarweni, Wiratna. 2015. SPSS Untuk Penelitian. Yogyakarta : Pustaka Baru Press

Witt, Stephen F. and Luiz Mountinho. 1994. Tourism Marketing and Management. Second Editio. 
Prentice Hall Internasional.

Woodside, A.G., Frey, L.L. and Daly, R.T. (1989). "Linking service quality, customer satisfaction, and behavioral intention". Journal of Health Care Marketing. Vol. 19. pp. 5-17.

Zeithaml, V.A., Marry Jo Bitner.2000.Service Marketing : Integrating Customer Focus Across the Firm. 2nd ed. International Edition. McGraw-Hil 